\title{
PENGARUH MULTIMEDIA MODEL TUTORIAL TERHADAP HASIL BELAJAR GAMBAR 3 DIMENSI SISWA SMK
}

\author{
Dian Rudiawan ${ }^{1}$, Ida Hamidah ${ }^{2}$, Mumu Komaro ${ }^{3}$ \\ Departemen Pendidikan Teknik Mesin \\ Universitas Pendidikan Indonesia \\ Jl. Dr. Setiabudhi No. 207 Bandung 40154 \\ dian.rudiawan@student.upi.edu
}

\begin{abstract}
ABSTRAK
Tujuan penelitian ini adalah untuk mendapatkan gambaran peningkatan hasil belajar siswa pada materi ajar solid editing kompetensi dasar membuat gambar 3 dimensi dengan menggunakan multimedia model tutorial dibandingkan dengan siswa yang menggunakan handout pada proses pembelajarannya. Penelitian ini dilakukan pada siswa SMK Negeri 12 Bandung menggunakan metode penelitian kuasi exsperimen. Sampel dalam penelitian ini adalah siswa kelas XII kompetensi keahlian kontruksi rangka pesawat udara, kelas eksperimen mendapatkan pembelajaran dengan multimedia model tutorial dan kelas kontrol mendapatkan pembelajaran dengan media handout. Hasil penelitian menunjukkan rata-rata pre-test kelas kontrol berada pada nilai 26 dan kelas eksperimen 30. Data tersebut menunjukan kedua kelas memiliki nilai rata-rata di bawah KKM. Hasil post-test pada kelas kontrol nilai rata-ratanya berada pada nilai 58 sedangkan kelas eksperimen nilai rata-ratanya berada pada nilai 90 . $\mathrm{N}$-Gain kelas eksperimen sebesar 0,87 dan kelas kontrol sebesar 0,43. Multimedia model tutorial lebih mampu meningkatkan hasil belajar siswa dibandingkan dengan media handout. Penelitian ini dapat disimpulkan bahwa pembelajaran dengan menggunakan multimedia model tutorial efektif untuk meningkatkan hasil belajar siswa pada materi ajar solid editing kompetensi dasar membuat gambar 3 dimensi.
\end{abstract}

Kata kunci: multimedia, tutorial, 3D, gambar, solid editing

\begin{abstract}
The purpose of this research is to get an idea of improving student learning outcomes in teaching materials solid editing basic competency in 3 dimensions image making by using multimedia tutorials models compared to students who use the handout in the learning process. This research was carried out on students of SMK Negeri 12 Bandung using a quasi-experimental research method. The sample in this study is a class XII student competency skills aircraft construction framework, which obtain experimental class learning with multimedia tutorials models while learning to gain control class handouts media. The results showed an average pre-test control class is at 26 and the value of the experimental class 30 . The data show both classes have an average value below the KKM. The results of the post-test control group the average value is at a value of 58 while the experimental class average value is at a value of 90 . The $\mathrm{N}$-Gain experimental class of 0.87 and 0.43 for the control class. It shows that multimedia tutorial models are better able to improve student learning outcomes than the media handouts. Multimedia tutorials models effectively to improve student learning outcomes in teaching materials solid editing basic competency in 3 dimensions image making.
\end{abstract}

Keywords: multimedia, tutorial, 3D, drawing, solid editing

\footnotetext{
${ }^{1}$ Mahasiswa Departemen Pendidikan Teknik Mesin FPTK UPI

${ }^{2}$ Dosen Departemen Pendidikan Teknik Mesin FPTK UPI

${ }^{3}$ Dosen Departemen Pendidikan Teknik Mesin FPTK UPI
} 


\section{PENDAHULUAN}

Sumber daya manusia yang memiliki kemampuan, keterampilan dan keahlian merupakan tanggung jawab dari salah satu lembaga pendidikan yaitu Sekolah Menengah Kejuruan (SMK). Perkembangan ilmu pengetahuan dan teknologi memaksa kita sebagai calon pendidik untuk berpikir keras agar cita-cita tersebut dapat tercapai dengan baik. Hal ini sesuai dengan tujuan SMK yaitu meningkatkan kemampuan siswa untuk dapat mengembangkan kemampuan diri yang sejalan dengan ilmu pengetahuan dan teknologi serta menyiapkan siswa untuk memasuki lapangan kerja dan menanamkan sikap profesional.

SMKN 12 Bandung merupakan sekolah kejuruan penerbangan yang menerapkan Kurikulum Tingkat Satuan Pendidik (KTSP) pada kelas XI dan kelas XII, dan menerapkan kurikulum 2013 pada kelas X, hal ini terjadi seiring dengan peralihan KTSP menjadi kurikulum 2013 secara bertahap sesuai dengan peraturan pemerintah. KTSP sendiri memiliki kerangka peraturan dimana isi dan bahan pelajaran serta cara penggunaannya disusun oleh SMK itu sendiri.

SMKN 12 Bandung khususnya pada jurusan Kontruksi Rangka Pesawat Udara, telah mengupayakan pengefektifan pembelajaran dengan didukung tenaga pengajar yang berkompeten dan fasilitas belajar yang terus dilengkapi. Namun hal ini masih dirasa belum cukup dalam pencapaian realisasi kurikulum. Kendala lainnya yang memungkinkan hal tersebut yaitu kurangnya pengemasan pelaksanaan pembelajaran yang cenderung tidak variatif dan kurang menarik minat siswa, dengan demikian perlu adanya evaluasi pelaksanaan pembelajaran.Di SMKN 12 Bandung khususnya Jurusan Teknik Rangka Pesawat Udara terdapat Mata Pelajaran Menggambar 3 Dimensi (3D) dengan system Computer Aided design (CAD). AutoCAD adalah sebuah program aplikasi (software) yang digunakan untuk menggambar dan mendisain gambar, seperti: gambar mesin, arsitek, sipil, elektro dan lain-lain. Program AutoCAD mempunyai kemudahan dan keunggulan untuk membuat gambar dengan cepat dan akurat serta memberikan hasil terbaik.

Menurut hasil observasi diperoleh data bahwa prestasi belajar siswa ketika mengikuti kegiatan UAS pada Mata Diklat Menggambar 3D dengan sistem CAD cukup rendah. Rendahnya prestasi belajar siswa desebabkan karena: (1) penyampaian materi oleh guru yang kadang terlalu cepat, padahal daya tangkap siswa bervariatif, sehingga banyak siswa yang kurang mampu menangkap materi pelajaran sepenuhnya; (2) kurangnya perhatian atau konsentrasi siswa terhadap apa yang disampaikan oleh guru; (3) penggunaan media pembelajaran berbasis komputer untuk perintah-perintah yang detail pada Mata 
diklat Menggambar 3D dengan sistem CAD belum digunakan oleh guru. Misalnya: penggunaan media pembelajaran menggunakan internet, compact disc (CD) multimedia interaktif, video pembelajaran, dan media berbasis komputer menggunakan software flash; berdasarkan identifikasi masalah yang dilihat dari satu tahun ke belakang, terlihat baik tujuan kompentesi dasar dan Kriteria Ketuntasan Minimal (KKM) yang telah ditetapkan tidak dapat tercapai. Rendahnya kompetensi Mata Diklat Menggambar 3D dengan Sistem CAD.

Menurut data yang diperoleh menyatakan bahwa para siswa tingkat XI KRPU SMKN 12 Bandung Semester Ganjil 2013/2014 pada mata pelajaran menggambar 3D dengan Sistem CAD mendapatkan nilai UAS sebelum diremedial yaitu di bawah KKM. Sedangkan KKM di SMKN 12 bandung adalah 7,5. Secara umum dapat dikatakan bahwa siswa belum lulus, padahal pelajaran AutoCAD sangat penting untuk siswa KRPU. Artinya proses pembelajaran menggunakan handout pada mata pelajaran AutoCAD yang selama ini digunakan di SMKN 12 Bandung dinilai kurang efektif. Sehingga perlunya metode lain sebagai pengganti supaya hasil belajar siswa bisa lebih baik lagi. Dengan tersedianya media komputer baik di sekolah maupun di lingkungan rumah siswa. Media pembelajaran bisa digunakan sebagai alat untuk mempermudah siswa dalam proses pembelajaran. Siswa dapat belajar tambahan mata pelajaran AutoCAD di rumah masing-masing setelah mendapat bimbingan guru di sekolahnya walaupun dengan kondisi waktu yang terbatas.

Media pembelajaran dalam pendidikan sebagai salah satu sarana meningkatkan mutu pendidikan sangat penting dalam proses pembelajaran. Penggunaan media pembelajaran dalam pendidikan dapat mempertinggi proses belajar siswa dalam poses belajar mengajar yang pada gilirannya dapat mempertinggi hasil belajar yang dicapainya (Arsyad, 2009). Bahwa manfaat media pembelajaran dalam proses belajar siswa, adalah sebagai berikut: (1) pembelajaran akan lebih menarik perhatian siswa sehingga dapat menumbuhkan motivasi belajar; (2) bahan pembelajaran akan lebih jelas maknanya sehingga dapat lebih dipahami oleh siswa dan memungkinkannya menguasai dan mencapai tujuan pembelajaran; (3) metode mengajar akan lebih bervariasi, tidak semata-mata komunikasi verbal melalui penuturan kata-kata oleh guru, sehingga siswa tidak bosan dan guru tidak kehabiasn tenaga, apalagi kalau guru mengajar pada setiap jam pelajaran; (4) siswa dapat lebih banyak melakukan kegiatan belajar sebab tidak hanya mendengarkan uraian guru, tetapi juga aktivitas lain seperti mengamati, melakukan, mendemonstrasikan, memerankan, dan lain-lain (Ariani dan Haryanto, 2010). 
Teknologi multimedia tidak bisa dipungkiri bahwa mampu memberi kesan dalam bidang media pembelajaran karena bisa mengintegrasikan teks, grafik, animasi, audio, dan video. Multimedia telah mengembangkan proses pengajaran dan pembelajaran kearah yang lebih dinamik. Namun lebih penting ialah pemahaman tentang bagaimana menggunakan teknologi tersebut dengan lebih efektif dan dapat menghasilkan ide untuk pengajaran dan pembelajaran. Pada masa sekarang, guru perlu mempunyai kemahiran dan keyakinan diri dalam menggunakan teknologi ini dengan cara yang berkesan. Dengan berkembangnya teknologi multimedia, penggunaan komputer multimedia dalam proses pengajaran dan pembelajaran adalah dengan tujuan meningkatkan mutu pengajaran dan pembelajaran (Sadiman, 1993). Unsur-unsur video, bunyi, teks dan grafik dapat dikemas menjadi satu melalui Pembelajaran Berbasis Komputer (PBK).

Multimedia interaktif adalah suatu multimedia yang dilengkapi dengan alat pengontrol yang dapat dioperasikan oleh pengguna, sehingga pengguna dapat memilih apa yang dikehendaki untuk proses selanjutnya (Anitah, 2009). Karakteristik multimedia interaktif adalah sebagai berikut: (1) memiliki lebih dari satu media yang konvergen misalnya menggabungkan audio dan visual; (2) bersifat interaktif, dalam pengertian memiliki kemampuan untuk mengakomodasi respon pengguna; (3) bersifat mandiri, dalam pengertian memberi kemudahan dan kelengkapan isi sedemikian rupa sehingga pengguna bisa menggunakan tanpa bimbingan orang lain; (4) mampu memperkuat respon pengguna secepatnya dan sesering mungkin; (5) mampu memberikan kesempatan kepada siswa untuk mengontrol laju kecepatan belajarnya sendiri; (6) memperhatikan bahwa siswa mengikuti suatu urutan yang jelas dan terkendali. Selain itu multimedia interaktif mampu memberikan kesempatan adanya partisipasi dari siswa dalam bentuk respon, baik berupa jawaban, pemilihan, keputusan, percobaan, dan lain-lain.

Multimedia model tutorial yang diterapkan memberikan pengaruh positif terhadap hasil belajar siswa. Beberapa penelitian yang berkaitan dengan penggunaan multimedia model tutorial pada materi ajar modify kompetensi dasar menggambar 2 dimensi dengan sistem CAD untuk meningkatkan hasil belajar siswa telah banyak dilakukan. Penelitian sebelumnya menunjukkan hasil yang didapatkan ternyata tingkat keberhasilan peserta didik kelas eksperimen yang menggunakan video tutorial hasinya lebih baik. Penggunaan media CD tutorial interaktif dan motivasi belajar terhadap hasil belajar siswa menyimpulkan bahwa menggunakan media CD tutorial interaktif membuat peningkatan pemahaman konsep siswa. 
Penggunaan multimedia model tutorial diasumsikan dapat mengatasi permasalahan rendahnya prestasi belajar siswa pada Kompetensi Dasar Membuat Gambar 3D. Selain itu, penggunaan multimedia model tutorialbisa menggantikan sebagian pekerjaan guru, sampai suatu hari nanti multimedia model tutorial bisa menggantikan seorang guru untuk menyampaikan materi kepada siswa. Multimedia model tutorial ini sangat cocok terhadap mata pelajaran AutoCAD yang mempunyai karakteristik sama (Sudjana, 2009). Salah satunya adalah belajar mandiri tanpa adanya guru. Sering banyak berlatih dengan memperhatikan suatu urutan yang jelas dan terkendali sesuai dengan ketentuan silabus atau kurikulum sekolah. Diakhiri dengan mengerjakan latihan soal yang hasilnya dapat diketahui oleh siswa. Sehingga materi yang kurang dipahami dapat dipelajari berulangulang lebih mendalam. Selain itu, siswa juga bisa mengontrol laju kecepatan belajarnya sendiri. Di SMKN 12 Bandung dapat dijadikan alternatif memperbaiki mutu pembelajaran Mata Diklat Menggambar 3D dengan sistem CAD. Menjadi solusi terbatasnya waktu pembelajaran didalam kelas bagi siswa-siswi dalam waktu pembelajaran Menggambar 3D dengan sistem CAD.

Tujuan penelitian ini, yaitu: mendapatkan gambaran peningkatan hasil belajar siswa pada materi ajar solid editing kompetensi dasar membuat gambar 3D dengan menggunakan handout. Mendapatkan gambaran peningkatan hasil belajar siswa pada materi ajar solid editing kompetensi dasar membuat gambar 3D dengan menggunakan multimedia model tutorial. Mendapatkan gambaran perbedaan peningkatan hasil belajar siswa dengan penggunaan multimedia model tutorial dibandingkan dengan penggunaan handout

\section{METODE PENELITIAN}

Metode penelitian yang digunakan adalah kuasi experimen. Rancangan penelitian kuasi eksperimen yang digunakan adalah dengan desain penelitian nonequivalent control group design. Subjek penelitian ada dua kelompok yaitu kelompok kontrol yaitu kelas yang tidak diberi perlakukan dan kelompok eksperimen yaitu kelas yang diberi perlakukan. Kelompok eksperimen yaitu kelas yang mendapatkan perlakuan pembelajaran dengan multimedia 3D dan kelompok kontrol dengan perlakuan handout. Kelas ekspeimen yaitu kelas XII KRPU 1. Kelas kontrol yaitu kelas XII KRPU 2. 


\section{HASIL PENELITIAN}

Data pre-test dan post-test pada kelas kontrol dan kelas eksperimen digunakan untuk menghitung nilai $\mathrm{N}$-Gain. Nilai $\mathrm{N}$-Gain dapat mencerminkan peningkatan pengetahuan siswa. Perhitungan nilai $\mathrm{N}$-Gain dimaksudkan untuk melihat peningkatan hasil belajar siswa antara yang menggunakan multimedia model tutorial dengan siswa yang menggunakan handout dalam proses pembelajarannya. Nilai rata-rata $N$-Gain yang diperoleh selanjutnya digunakan untuk melakukan pengujian terhadap hipotesis, sebelum pengujian hipotesis dilakukan maka terlebih dahulu dilakukan pengujian normalitas dan homogenitas sebagai syarat dalam melakukan pengujian hipotesis.

Tabel 1. Data Hasil Pre-test Kelas Eksperimen dan Kelas Kontrol

\begin{tabular}{ccc}
\hline \multirow{2}{*}{ Skor } & \multicolumn{2}{c}{ Frekuensi } \\
\cline { 2 - 3 } & Kontrol & Eksperimen \\
\hline $0-10$ & 3 & 2 \\
\hline $11-20$ & 9 & 2 \\
\hline $21-30$ & 6 & 9 \\
\hline $31-40$ & 9 & 9 \\
\hline $41-50$ & 3 & 2 \\
\hline $51-60$ & 0 & 1 \\
\hline $\begin{array}{c}\text { Rata-rata } \\
\text { Pre-test }\end{array}$ & 30 & 26 \\
\hline
\end{tabular}

Nilai rata-rata pre-test kelas kontrol berada pada nilai 26 dan kelas eksperimen yaitu 30. Data tersebut (Tabel 1) menunjukkan adanya perbedaan antara kedua kelas. Hal tersebut menandakan kemampuan awal dari kedua kelas yakni kelas kontrol dan kelas eksperimen tidak jauh berbeda. Data tersebut diperkuat pula dengan melakukan pengujian homogenitas terhadap kedua kelas dengan menggunakan uji $\mathrm{F}$, didapatkan bahwa kedua sampel kelas homogen dengan taraf signifikansi sebesar 10\%, nilai ini lebih besar dari taraf signifikansi yang telah ditentukan yaitu sebesar 5\%. Kedua sampel kelas tersebut homogen sehingga kedua kelas dapat digunakan untuk penelitian dan dapat diberikan perlakuan (treatment). Berbeda dengan hasil pre-test, hasil post-test menunjukkan perbedaan yang signifikan.

Data pada Tabel 2 menampilkan nilai rata-rata post-test kelas kontrol lebih rendah dibandingkan kelas eksperimen. Kelas kontrol yang diberikan pembelajaran dengan menggunakan handout nilai rata-ratanya berada pada nilai 58 sedangkan kelas eksperimen yang pembelajarannya diberikan dengan menggunakan multimedia model tutorial nilai rata-ratanya berada pada nilai 90 . 
Tabel 2. Data Hasil Post-test Kelas Eksperimen dan Kelas Kontrol

\begin{tabular}{ccc}
\hline \multirow{2}{*}{ Skor } & \multicolumn{2}{c}{ Frekuensi } \\
\cline { 2 - 3 } & Kontrol & Eksperimen \\
\hline $0-20$ & - & - \\
\hline $21-40$ & 6 & - \\
\hline $41-60$ & 17 & 1 \\
\hline $61-80$ & 1 & 6 \\
\hline $81-100$ & 6 & 18 \\
\hline $\begin{array}{l}\text { Rata-rata } \\
\text { Post-test }\end{array}$ & 58 & 90 \\
\hline
\end{tabular}

Data nilai rata-rata $N$-Gain juga sejalan dengan data hasil post-test. Data menunjukkan adanya perbedaan antara kedua kelas yaitu kelas kontrol dan kelas eksperimen.

Tabel 3. Data N-Gain

\begin{tabular}{lccc}
\hline \multicolumn{1}{c}{ Data } & Rata-rata N-Gain & Kategori & Frekuensi \\
\hline \multirow{3}{*}{ Kelas Kontrol } & \multirow{2}{*}{0.43} & Tinggi & 7 \\
\cline { 3 - 4 } & & Sedang & 14 \\
\cline { 3 - 4 } Kelas Eksperimen & \multirow{2}{*}{0.87} & Rendah & 9 \\
\cline { 3 - 4 } & & Tinggi & 19 \\
\cline { 3 - 4 } & & Sedang & 5 \\
\hline
\end{tabular}

Nilai rata-rata $N$-Gain kelas kontrol (Tabel 3) sebesar 0,43 dimana nilai tersebut berada dalam kategori sedang. Sedangkan nilai rata-rata kelas eksperimen yaitu sebesar 0,87 dimana nilai tersebut berada dalam kategori tinggi. Perbedaan nilai rata-rata $\mathrm{N}$-Gain kedua kelas yaitu kelas kontrol dan kelas eksperimen dapat dilihat denga jelas.

Data yang diperoleh melalui proses pemberian pre-test dan post-test pada kelas kontrol dan kelas eksperimen selanjutnya dilakukan proses penghitungan dan analisis untuk menentukan langkah selanjutnya dalam penelitian dan pengujian hipotesis. Pengujian yang dilakukan terhadap data-data yang didapatkan yaitu pengujian homogenitas, pengujian normalitas dan pengujian hipotesis. Pengujian homogenitas dimaksudkan untuk mengetahui keadaan awal kedua sampel sama atau tidak sehingga mendapatkan keputusan bahwa kelas dapat digunakan atau tidak dapat digunakan dalam melakukan proses penelitian. Pengujian normalitas dilakukan dengan maksud untuk mengetahui apakah data yang didapatkan terdistribusi normal atau tidak. Kedua pengujian yaitu pengujian homogenitas dan normalitas selanjutnya digunakan untuk menentukan langkah pengujian yang dilakukan dengan menggunakan statistik parametrik atau non 
parametrik. Apabila setelah dilakukan proses pengujian data dinyatakan homogen dan terdistribusi normal maka selanjutnya digunakan statistik parametrik dan apabila tidak maka digunakan statistik non parametrik.

Pengujian homogenitas dilakukan pada data pre-test kedua sampel kelas. Pengujian normalitas dilakukan pada data pre-test dan post-test kedua kelas sampel. Pengujian hipotesis dilakukan pada data N-Gain. Data-data tersebut dapat dilihat pada Tabel 4.

Tabel 4. Hasil Pengujian Homogenitas, Normalitas dan Hipotesis

\begin{tabular}{|c|c|c|c|c|c|c|}
\hline \multirow[t]{2}{*}{ Data } & \multicolumn{2}{|c|}{$\begin{array}{l}\text { Uji Homogenitas } \\
\text { (Uji F) }\end{array}$} & \multicolumn{2}{|c|}{$\begin{array}{c}\text { Uji Normalitas } \\
\text { Kolmogorov-Smirnov } \alpha= \\
0,05\end{array}$} & \multicolumn{2}{|c|}{$\begin{array}{c}\text { Uji Hipotesis } \\
\text { Uji T }\end{array}$} \\
\hline & p-value & Kondisi & signifikansi & Kondisi & signifikansi & Kondis \\
\hline \multirow{2}{*}{$\begin{array}{c}\text { Pre- } \\
\text { test }\end{array}$} & \multirow{2}{*}{$\begin{array}{l}p \text {-value }= \\
0,10 \\
\alpha=0,05 \\
p \text {-value }>\alpha\end{array}$} & \multirow{2}{*}{$\begin{array}{l}\text { Dua Kelas } \\
\text { Homogen }\end{array}$} & $\begin{array}{l}\text { kelas kontrol } \\
0,86\end{array}$ & Normal & \multirow[b]{2}{*}{ - } & \multirow[b]{2}{*}{-} \\
\hline & & & $\begin{array}{l}\text { kelas } \\
\text { eksperimen } \\
0,57\end{array}$ & Normal & & \\
\hline \multirow{2}{*}{$\begin{array}{c}\text { Post- } \\
\text { test }\end{array}$} & \multirow{2}{*}{$\begin{array}{l}p \text {-value }= \\
0,15 \\
\alpha=0,05 \\
p \text {-value }>\alpha\end{array}$} & \multirow{2}{*}{$\begin{array}{l}\text { Dua Kelas } \\
\text { Homogen }\end{array}$} & $\begin{array}{l}\text { Kelas control } \\
0,08\end{array}$ & Normal & \multirow[b]{2}{*}{-} & \multirow[b]{2}{*}{-} \\
\hline & & & $\begin{array}{l}\text { Kelas } \\
\text { eksperimen } \\
0,27 \\
\end{array}$ & Normal & & \\
\hline \multirow{2}{*}{$\begin{array}{l}N- \\
\text { Gain }\end{array}$} & \multirow{2}{*}{ - } & \multirow{2}{*}{ - } & $\begin{array}{ll}\text { kelas } & \text { kontrol } \\
0,37 & \end{array}$ & Normal & \multirow{2}{*}{$\begin{array}{l}0,000< \\
0,05\end{array}$} & \multirow{2}{*}{$\begin{array}{c}\mathrm{H}_{\mathrm{o}} \\
\text { Ditolak }\end{array}$} \\
\hline & & & $\begin{array}{l}\text { kelas } \\
\text { eksperimen } \\
0,21\end{array}$ & Normal & & \\
\hline
\end{tabular}

Pengujian homogenitas dilakukan pada data pre-test dan post-test untuk kedua kelas. Hasil perhitungan homogenitas pre-test menunjukkan $p$-value yang diperoleh yaitu 0,10 . Nilai yang diperoleh dalam perhitungan lebih besar dibandingkan taraf signifikansi yang ditetapkan yaitu sebesar 0,05 , ini berarti $p$-value $=0,10>\alpha=0,05$. Maka hasil perhitungan tersebut berarti bahwa dua kelas sampel tersebut homogen, sehingga kedua kelas sampel dapat diberikan perlakuan (treatment) dan digunakan untuk penelitian. Pengujian normalitas dilakukan pada data pre-test dan post-test dari kedua kelas sampel. Hasil pengujian normalitas pada data pre-test didapatkan signifikansi untuk kelas kontrol sebesar 0,86 dan kelas eksperimen sebesar 0,57. Hasil pengujian normalitas dari kedua kelas sampel lebih besar dari taraf signifikansi yang telah ditetapkan yaitu 0,05 , dapat dikatakan untuk kelas kontrol signifikansi $=0,86<\alpha=0,05$ dan untuk kelas eksperimen signifikansi $=0,57>\alpha=0,05$. Hasil tersebut memiliki arti bahwa untuk data pre-test pada kedua kelas sampel tersebut normal. 
Hasil pengujian normalitas data post-test didapatkan signifikansi untuk kelas kontrol sebesar 0,08 dan kelas eksperimen sebesar 0,27. Hasil pengujian normalitas dari kedua kelas sampel lebih besar dari taraf signifikansi yang telah ditetapkan sebesar 0,05, , dapat dikatakan untuk kelas kontrol signifikansi $=0,08>\alpha=0,05$ dan untuk kelas eksperimen signifikansi $=0,27>\alpha=0,05$. Hasil tersebut memiliki arti bahwa untuk data post-test pada kedua kelas sampel tersebut normal.

Pengujian hipotesis pada penelitian ini dilakukan pada data $N$-Gain. Pengujian ini dilakukan dengan menggunakan uji wilcoxon, setelah dilakukan pengujian didapatkan nilai negative rank $=1$ (nilai kelas control hanya ada 1 yang lebih tinggi dari nilai kelas eksperimen) sedangkan positive rank $=24$ (ada 24 nilai kelas eksperimen yang lebih tinggi dari pada nilai kelas control). Maka dapat ditarik kesimpulan bahwa dari signifikansi adalah $0,00<0,05$. ini berarti bahwa $\mathrm{H}_{\mathrm{o}}$ ditolak atau berarti bahwa terdapat peningkatan hasil belajar siswa yang menggunakan multimedia model tutorial pada proses pembelajarannya atau peningkatan hasil belajar siswa yang menggunakan multimedia model tutorial lebih baik dibandingkan dengan siswa yang menggunakan handout.

\section{PEMBAHASAN}

Analisis data yang telah dilakukan menunjukkan bahwa adanya pengaruh terhadap hasil belajar siswa yang diberikan pembelajaran dengan menggunakan multimedia model tutorial. Ini ditunjukkan dengan hasil post-test dan nilai rata-rata $\mathrm{N}$-Gain kelas eksperimen yang lebih besar nilainya dibandingkan dengan kelas kontrol. Seperti yang diketahui bahwa kelas eksperimen diberikan pembelajaran menggunakan multimedia model tutorial sedangkan kelas kontrol diberikan pembelajaran dengan menggunakan handout. Hasil pengujian hipotesis terhadap data $\mathrm{N}$-Gain pun menunjukkan bahwa $\mathrm{H}_{\mathrm{A}}$ diterima yang berarti bahwa peningkatan hasil belajar siswa yang menggunakan multimedia model tutorial pada proses pembelajarannya lebih baik dibandingkan dengan hasil belajar siswa yang menggunakan handout pada proses pembelajarannya.

Manfaat multimedia, diantaranya multimedia dapat memberikan kemudahan bagi penggunanya, dengan multimedia model tutorial proses pembelajaran bisa dilakukan berulang hingga pengguna dapat mengerti materi yang disampaikan dalam multimedia tersebut. Multimedia pembelajaran ini juga dapat membuat proses belajar yang dirasa monoton menjadi menarik, menumbuhkan minat belajar, tidak membuat bosan karena banyak melibatkan interaksi sehingga dapat menimbulkan motivasi dalam belajar (Soenarto, 2006). Penelitian ini menggunakan multimedia pembelajaran jenis multimedia 
model tutorial yang apabila dikaitkan dengan karakteristik mata pelajaran autocad mampu mengatasi permasalahan yang dihadapi. Masalah pembelajaran autocad dinilai mampu diatasi dengan multimedia model tutorial, karena multimedia ini mampu menarik perhatian siswa dan ditampilkan dengan arahan serta tampilan yang tidak membosankan.

Manfaat pemakaian multimedia pengajaran dalam proses belajar mengajar dapat membangkitkan keinginan dan minat yang baru, membangkitkan motivasi dan rangsangan kegiatan belajar dan bahkan membawa pengaruh psikologis terhadap siswa (Arsyad, 2009). Multimedia pembelajaran merupakan hasil dari sebuah budaya yang secara jelas untuk proses belajar dan mengajar. Hal ini karena segala proses dari awal sampai selesainya proses tersebut harus mencerminkan pembelajaran itu sendiri. Sebagai suatu usaha yang sadar dan disengaja, bertujuan jelas dan pelaksanaanya terkendali.

Fungsi multimedia pembelajaran dalam proses belajar siswa adalah: pembelajaran akan lebih menarik perhatian siswa sehingga dapat menumbuhkan motivasi belajar; bahan pembelajaran akan lebih jelas maknanya sehingga dapat lebih dipahami oleh siswa dan memungkinkannya menguasai dan mencapai tujuan pembelajaran; metode mengajar akan lebih bervariasi, tidak semata-mata komunikasi verbal melalui penuturan kata-kata oleh guru. Sehingga siswa tidak bosan dan guru tidak kehabisan tenaga. Apalagi kalau guru mengajar pada setiap jam pembelajaran; siswa dapat lebih banyak melakukan kegiatan belajar sebab tidak hanya mendengarkan uraian guru, tetapi juga aktivitas lain seperti mengamati, melakukan, mendemonstrasikan, dan memerankan (Hamalik, 2004).

Fungsi multimedia pembelajaran diantaranya: memperjelas dan memperkaya/ melengkapi informasi yang diberikan secara verbal; meningkatkan motivasi dan efisiensi penyampaian informasi; meningkatkan efektivitas dan efisiensi penyampain informasi; menambah variasi penyajian materi; pemilihan multimedia yang tepat akan menimbulkan semangat, gairah dan mencegah kebosanan siswa untuk belajar; kemudahan materi untuk dicerna dan lebih membekas, sehingga tidak mudah dilupakan siswa; dan memberikan pengalaman lebih kongrit bagi hal yang mungkin abstrak (Nurhayati dan Lukman, 2004).

Kesimpulannya bahwa multimedia pembelajaran dapat membangkitkan keinginan peserta didik, dapat meningkatkan minat peserta didik dalam pengajaran yang pada akhirnya menumbuhkan motivasi peserta didik untuk belajar dan meningkatkan hasil belajar siswa. Multimedia model tutorial yang digunakan dalam penelitian ini berpengaruh baik terhadap tingkat hasil belajar siswa pada materi ajar solid editing. Hasil penelitian menunjukkan bahwa peningkatan hasil belajar siswa pada materi solid editing yang 
menggunakan multimedia model tutorial pada proses pembelajarannya lebih baik dibandingkan dengan yang menggunakan handout.

\section{KESIMPULAN}

Kesimpulan penelitian ini yaitu pembelajaran menggunakan multimedia model tutorial dapat memberikan peningkatan hasil belajar siswa pada materi ajar solid editing kompetensi dasar membuat gambar 3D lebih baik dibandingkan dengan pembelajaran yang menggunakan handout. Peningkatan hasil belajar siswa pada materi ajar solid editing kompetensi dasar membuat gambar 3D dengan menggunakan multimedia model tutorial lebih baik dibandingkan dengan siswa yang menggunakan diktat pada proses pembelajarannya.

\section{DAFTAR PUSTAKA}

Anitah, S. (2009). Media pembelajaran. Surakarta: Yuma Pustaka

Ariani, N. dan Haryanto, D. (2010). Pembelajaran Multimedia di Sekolah Pedoman Pembelajaran Inspiratif, Konstruktif, dan Prospektif. Jakarta: Prestasi Pustaka.

Arsyad, A. (2009). Media Pembelajaran.Jakarta: PT. Raja Grafindo Persada.

Hamalik, O. (2004). Proses Belajar mengajar. Jakarta: Bumi Aksara

Nurhayati dan Lukman (2004). Media Pembelajaran Animasi. [Online]. Tersedia http://faizalnizbah.blogspot.com/2013/07/media-pembelajaran-animasi.html.

Sadiman, A.S. et al. (1993). Media Pendidikan, Pengertian, Pengembangan, dan Pemanfaatannya. Jakarta: PT. Raja Grafindo Persada.

Soenarto, (2006). Sistem Evaluasi Pendidikan Teknologi dan Kejuruan. Bandung: SPs UPI.

Sudjana, Nana. (2009). Penilaian Hasil Proses Belajar Mengajar. Bandung: Remaja Rosdakarya. 